\title{
Aniela Radecka
}

Uniwersytet Wrocławski aniela.radecka@gmail.com

\section{Ciało jako fundament tożsamości? Próby (re)konstrukcji kobiecej tożsamości na podstawie powieści Siomga ukraińskiej pisarki Sofiji Andruchowycz}

W centrum rozważań w niniejszym artykule znajduje się powieść Siomga i zawarte w niej próby rekonstrukcji kobiecej tożsamości na gruncie postkolonialno-posttotalitarnej rzeczywistości ukraińskiej. Autorka odwołuje się do koncepcji somatekstu, feminizmu korporalnego oraz ukraińskiej wersji herstory.

Słowa kluczowe: feminizm korporalny, cielesność, tożsamość, ukraińska proza kobieca

Celem niniejszego artykułu jest próba analizy powieści Sofiji Andruchowycz Siomga z perspektywy feminizmu korporalnego i teorii postkolonialnej ${ }^{1}$. Feminizm korporalny, jako jeden z odłamów krytyki feministycznej, to prężnie rozwijający się nurt odnoszący się do tekstów kultury zapośredniczonych przez doświadczenie cielesne. Proponuje on

${ }^{1} \mathrm{O}$ zasadności zastosowania teorii postkolonialnej na gruncie ukraińskim pisze Tamara Hundorowa, por. Т. Гундорова, Postorientalizm, romans imigrancki i nowe możliwości studiów postkolonialnych w Europie Wschodniej: Zarys dziejów traktora po ukraińsku Mariny Lewyckiej, tłum. M. Mularczyk, „Miscellanea Posttotalitariana Wratislaviensia", 2/2014, s. 87-106. 
odpowiednie instrumentarium do analizy powieści Siomga, gdyż sam „feminizm ma szczególny stosunek do problemu ciała. Interesuje się nim znacznie dłużej niż ci, którzy dopiero teraz dostrzegli »historyczną wagę« tego tematu. Brak głębszego zainteresowania cielesnością łączył się zapewne $\mathrm{z}$ wielowiekową tradycją uznawanego za nader oczywisty w myśli zachodniej podstawowego dualizmu umysłu i ciała. W kontekście tej tradycji kobieta sytuowana była (i jest nadal) »po stronie ciała«. Umysł był głównie specjalnością mężczyzn"2.

Według Urszuli Śmietany, w kulturze XX wieku ciało jawi się jako najbardziej trwała, znacząca i rozpoznawalna ikona, swoiste signum temporis współczesności i ponowoczesności. Dwudziestowieczny portret ciała ludzkiego to szczególny w swej treści collage obrazów medialnych, naukowych, religijnych oraz artystycznych ${ }^{3}$. Dla badaczki staje się więc ono wyjściem do rozważań nad warunkami i kontekstami „somatyzacji” kultury i tożsamości zachodnioeuropejskiej ${ }^{4}$, warto jednak zwrócić się w kierunku Europy Wschodniej, tożsamości i kultury wschodnioeuropejskiej, w większości postkolonialno-posttotalitarnej. Znamienny w okresie istnienia ZSRR był brak prawa do świadomego posiadania ciała jako takiego w przestrzeni nie tylko publicznej (oficjalnej, państwowej), ale także prywatnej - całe społeczności zostały go pozbawione. Homo sovieticus nie miał prawa do świadomej kontroli nad własnym umysłem czy ciałem - inaczej zachowałby choć odrobinę niezależności od władzy, dla której pozostawał jedynie częścią biernej masy społecznej. Ludzie byli traktowani jak ciała pozbawione tożsamości i zinstrumentalizowane $\mathrm{w}$ ramach systemu totalitarnego ${ }^{5}$. Stąd często drogą ucieczki do wolności okazywała się choroba, szaleństwo, melancholia czy w skrajnych przypadkach - samobójstwo.

${ }^{2}$ E. Hyży, Kobieta, ciało, tożsamość. Teorie podmiotu $w$ filozofii feministycznej końca XX wieku, Kraków 2012, s. 16-17.

${ }^{3}$ U. Śmietana, Od écriture féminine do somatekstu, „Przegląd Filozoficzno-Literacki”, 1(3)/2003, s. 153.

${ }^{4}$ Tamże.

${ }^{5}$ A. Dziadek, Projekt krytyki somatycznej, Warszawa 2014, s. 9. 


\section{Ciało literatury ukraińskiej - przełom epok}

Pokolenie pisarzy ukraińskich debiutujące u schyłku ZSRR stawia cielesność na piedestale. Jest ona jednym z podstawowych elementów literackiego postmodernizmu, należy jednak odnotować, mimo istniejących męskich i kobiecych narracji, że najczęściej mamy do czynienia $\mathrm{z}$ tą pierwszą. Kobiece ciało w większości przypadków opisywane jest z perspektywy autora mężczyzny, jest uprzedmiotowione, jak w powieściach Jurija Andruchowycza (Moskowiada, Perwesja), Wiaczesława Medwid'a (Życie w haremie) czy Jurija Pokalczuka ( $Z$ drugiej ręki). Jak zauważa Wira Agejewa, literatura lat osiemdziesiątych i dziewięćdziesiątych rozwija się w klimacie oszołomienia wolnością, w obliczu zniesienia potężnych jeszcze niedawno zakazów i tabu, a fabuła często przyozdabiana jest niewymyślną erotyką czy scenami gwałtu. Jedną z cech charakterystycznych wielu tekstów pisanych przez mężczyzn staje się demonstrowanie ordynarnego machizmu6 .

Pierwszym kobiecym głosem na niepodległej Ukrainie jest oczywiście twórczość wybitnej pisarki Oksany Zabużko i jej debiutancka powieść Badania terenowe nad ukraińskim seksem (1996). Jak zauważa Rosi Braidotti, to właśnie sztuka kobieca, neutralizując arystotelesowsko-kartezjański aksjomat rozdziału duszy i ciała, spełniając zarazem ważne funkcje demaskatorskie i kontestacyjne wobec idealizujących czy konsumpcyjnych postaw wobec ciała, przypomniała, iż ludzka egzystencja wypełniona jest cielesną treścią, a cielesność jest formułą człowieczego przejawiania się w świecie ${ }^{7}$. Powieść Zabużko w formie herstorycznego monologu jest próbą przepracowania postkolonialno-posttotalitarnej traumy, która w ukraińskim wydaniu po 1991 roku przejawia się m.in. jako rozbicie tożsamości jednostki, brak swojego

${ }^{6}$ W. Agejewa, Kobieta-autor i kobieta-czytelnik we współczesnej literaturze ukraińskiej, [w:] E. Kraskowska (red.), Literatury słowiańskie po roku 1989. Nowe zjawiska, tendencje, perspektywy, t. 2: Feminizm, Warszawa 2005, s. 109-110.

${ }^{7}$ R. Braidotti, Podmiot $w$ feminizmie, tłum. A. Borowska, ,Kwartalnik Pedagogiczny”, 1/2/1995, za: U. Śmietana, Od écriture féminine..., s. 154. 
miejsca w społeczeństwie, degradacja roli rodziny i wspólnoty, negacja dotychczasowych paradygmatów.

(O)powiedzenie siebie i swojej historii za pomocą intymnego doświadczenia ciała staje się jednym ze sposobów poszukiwania tożsamości w nowej ukraińskiej rzeczywistości, co jest szczególnie traumatyczne dla kobiet. Świadczy o tym chociażby recepcja powieści Zabużko wśród krytyków: oskarżono ją o zamach na społeczną moralność i aurę świętości otaczającą wyobrażenie ukraińskiej kobiety ${ }^{8}$. Autorka w swojej mikropowieści przełamuje obowiązujące tabu, otwarcie pisząc o kobiecej seksualności, cielesności, relacjach damsko-męskich, używając przy tym nienormatywnej leksyki, prowadząc emocjonalną narrację. Wszystko to było do przyjęcia przez krytykę jedynie w wykonaniu autorów mężczyzn, gdy jednak kobieta podjęła się wyzwania opowiedzenia swojej traumy, próby rekonstrukcji losów rodziny i narodu, okazało się to skandalem. Obecność narracji o ciele, szczególnie autorstwa kobiet, pozostaje na gruncie ukraińskiej literatury materią nie do końca przeanalizowaną - niektórzy krytycy czują się usprawiedliwieni, jako przykład cielesności kobiecej analizując jedynie twórczość Oksany Zabużko i nie nawiązując do utworów innych współczesnych autorek. Cielesność staje się jednak tematem, który coraz częściej przykuwa uwagę ukraińskich badaczy i być może stanie się jednym z tematów rozwijanych przez współczesnych krytyków ${ }^{9}$.

\section{Siomga - ukraińska herstory}

Ponad dziesięć lat po debiucie Zabużko Sofija Andruchowycz (ur. 1982), należąca do kolejnego pokolenia ukraińskich pisarek, pisze jedną ze swoich najważniejszych powieści - Siomga (2007). Utwór ten odebrano na Ukrainie jako skandal, nie zagłębiono się w niuanse odnoszące się do ukraińskiej rzeczywistości, przemycane przez autorkę pod

\footnotetext{
${ }^{8}$ W. Agejewa, Kobieta-autor i kobieta-czytelnik..., s. 112-113.

${ }^{9}$ Zob. m.in. Я. Поліщук, Реактивність літератури, Київ 2016.
} 
powierzchnią pozornie nic nieznaczącego potoku wspomnień głównej bohaterki. Protagonistka powieści w swoich wspomnieniach przywołuje obrazy przemocy (w tym seksualnej) stosowanej wobec kobiet i dzieci, ale krytyka skupiła się przede wszystkim na dosłownych opisach miłości cielesnej i ciała kobiety jako takiego. Świadczy to o tym, iż nadal obowiązuje tabu kobiecego ciała i seksualności w ukraińskiej przestrzeni publicznej. Opowieść głównej bohaterki Sofiji (autorka nadała protagonistce nie tylko swoje imię, ale także nazwisko ${ }^{10}$ ) oparta jest w dużej części na pamięci ciała. Narratorka w osobie dojrzewającej kobiety odtwarza wydarzenia z dzieciństwa i okresu dojrzewania, a jej światem rządzą emocje: „Mogę wymyślać cokolwiek, mogę zachowywać dokumentalną dokładność, opowiadać to, co wiem, opisywać to, co sama widziałam - a i tak zawsze będę mówić tylko o sobie. Opisując innych ludzi, ich wygląd i słowa - będę opisywać jedynie siebie samą. W innych nie mogę zobaczyć niczego poza swoim odbiciem" "11. W centrum opowieści jest narratorka, opisująca swoje ja w kontekście zaistniałych okoliczności i w odniesieniu do różnych osób. Jedną z kluczowych postaci w powieści jest anonimowy obserwator, który podgląda bohaterkę i jej partnera w ich mieszkaniu: „Teoretycznie mogłabym go do nas zaprosić, żeby naprawił kran w kuchni. Praktycznie już na samą myśl o nim przechodzą mnie ciarki i boję się wrócić do pokoju. [...] Nasz pokój, dziesięć metrów kwadratowych - to jego telewizor. Albo akwarium. Albo klatka z chomikami"' 12 . Zgodnie z sugestią autorki, która nadała protagonistce powieści cechy autobiograficzne, należy przypuszczać, że powieściowa Sofija to młoda kobieta, wychowana na Zachodniej Ukrainie, a mieszkająca w Kijowie, w budynku przy ulicy Robotniczej 7a, którego nie można odnaleźć na żadnej mapie ${ }^{13}$. Wychodząc od pamięci ciała i procesów w nim zachodzących, opisuje ona otaczającą ją rzeczy-

\footnotetext{
${ }^{10}$ Zob. S. Andruchowycz, Siomga, tłum. M. Petryk, Wołowiec 2009, s. 324.

${ }^{11}$ Tamże, s. 79.

12 Tamże, s. 6.

${ }^{13}$ Tamże, s. 13.
} 
wistość: „I wtedy ogarnęła mnie panika. On tam jest, za oknem, znów przyszedł, znów na mnie patrzy. Widzi mnie, słyszy mój oddech, ogląda rumieńce na moich policzkach i pasma mokrych, potarganych włosów. Jego wzrok jest tak wyostrzony i wyczulony, że wyraźnie, niczym przez szkło powiększające, widzi najdrobniejsze włoski na moim ciele i może z zamkniętymi oczami narysować na zaparowanej od swojego oddechu szybie kontury bladego znamiona w kształcie motyla, które mam po wewnętrznej stronie prawego uda"14.

Siomga staje się narracją ciała i o ciele, dlatego też lektura staje się aktem (od)czytania śladów obecności ciała w utworze. Tekst kultury, pozostający $\mathrm{w}$ opozycji do paradygmatu fallocentrycznego, może się stać somatekstem, ,ilustrującym pewien rodzaj świadomości zapośredniczonej przez ciało, wspierającej się na jego znaczącej, choć niejednoznacznej obecności. Somatekst świadomie sublimuje doświadczenie somatyczne w artystyczną jakość i artykulacja ta, choć silnie zindywidualizowana i zróżnicowana, tworzy pewien typ tożsamości i typ podmiotu, który ją konstruuje" ${ }^{15}$. Powieść Andruchowycz przez pryzmat doświadczenia ciała opowiada historię dojrzewania dziewczynki, nastolatki, a wreszcie młodej kobiety, sublimując owo somatyczne doświadczenie w artystyczną jakość. Według Moniki Świerkosz „ciało to pierwsze miejsce zamieszkania podmiotu i jego punkt orientacyjny na świat. To również główny rezonator dla każdej opowieści podmiotu, ale i kulturowy znak ograniczoności podmiotu wobec świata i Innego"16. Siomga jest z pozoru opowieścią o jednostce, która za pomocą „wyskrobywania z pamięci" 17 rekonstruuje nie tylko szczegóły z własnego życia, ale także ukraińską rzeczywistość okresu tranzycji. To „próba poskładania człowieka z miliarda szczegółów, znaczących i mało ważnych wydarzeń, wspomnień, ran, obrażeń, traum. Złożenia w jedno, aby póź-

${ }^{14}$ Tamże, s. 8

${ }^{15}$ U. Śmietana, Od écriture féminine..., s. 168.

${ }^{16}$ M. Świerkosz, Feminizm korporalny $w$ badaniach literackich. Próba wyjścia poza metaforykę cielesności, „Teksty Drugie”, 1-2/2008, s. 83.

${ }^{17}$ S. Andruchowycz, Siomga, s. 87. 
niej móc rozbić go na drobne kawałki, żeby mieć możliwość składania go znów i znów, za każdym razem dodając coś nowego, zmieniając go po trochu lub w pełni"

Bogusław Bakuła wymienia jako jeden z elementów narracji postkolonialnej tzw. dyskurs o sobie. To „wzmożona autorefleksja dotycząca historii narodowej zależności, jak i spraw, które z niej wyrastają w czasach współczesnych. Swego rodzaju nadmiar tekstów, poświęconych analizie własnej sytuacji, sygnalizuje istnienie sytuacji kryzysowej związanej z chronicznym brakiem wolności, słabością, świadomością klęski historycznej, jaką jest upadek państwa, rozbicie społeczeństwa"19. Pokolenie protagonistki Siomgi w żadnym wypadku nie jest pokoleniem wolnym od kolonialnej i totalitarnej, traumatogennej spuścizny historycznej. Urodzone w ZSRR, dorasta na przełomie epok, co stawia wiele wyzwań wobec społeczeństwa i jednostki. Częściowo pokolenie to miało styczność z poprzednim systemem, chociażby w okresie wczesnego dzieciństwa: „Przedszkolanki nie musiały udawać. I w snach, i na jawie wyglądały jednakowo strasznie. [...] - Porozrywam na kawałki! Rozszarpię! Zaduszę! Zabiję! Zakopię! Ze sraczką i smarkami pomieszam! [...] - wściekała się, miotając jak w gorączce. Potem obiema rękami łapała jeszcze jeden fotelik i waliła, waliła, waliła nim o ściany i stó1"'20.

Zarówno przedszkole, jak i regularne wyjazdy do nadmorskich sanatoriów stanowiły jedne z elementów sowieckiej codzienności - systemu przepełnionego rytuałami i rygorem, które trzymały społeczeństwo w ryzach. „Władza przekłada się wprost na czas: zapewnia kontrolę nad nim i gwarantuje jego wykorzystanie. Procedury dyscyplinarne wydo-

${ }^{18}$ Софія Андрухович: „Сьомга” - уявний сеанс психотерапії. I стриптиз. I харакірі..., tłum. własne [http://portal.lviv.ua/ratusha/2007/04/12/143153 [dostęp: 18.10.2016].

${ }^{19}$ B. Bakuła, Europa Środkowo-Wschodnia i jej (post)kolonialny świat, [w:] B. Bakuła (red.), Dyskurs postkolonialny we współczesnej literaturze i kulturze Europy Środkowo-Wschodniej. Polska, Ukraina, Wegry, Słowacja, Poznań 2015, s. 76.

${ }^{20}$ S. Andruchowycz, Siomga, s. 141-143. 
bywają na jaw linearność czasu, integrującego jedne jego fragmenty z następnymi, zmierzającego ku stałemu punktowi końcowemu" ${ }^{21}$. Obowiązkowym w krajobrazie tworzonym przez Andruchowycz jest szpital psychiatryczny, kolejna z instytucji dyscyplinujących społeczeństwo za pomocą kontrolowania ciała: ,Zapomniałam wspomnieć o zapachu a była to chyba najważniejsza rzecz na terytorium wariatkowa. Nawet zza muru, nawet gdy nie przekraczało się granicy, czuło się już tę ciężką, gęstą, potworną mieszaninę, żrącą i trującą. Zwalała mi się na ramiona, wsączała przez pory skóry, bardzo trudno było się jej pozbyć - to jeden z zapachów, które wżerają się niemal na wieczność. Zapach domu wariatów był jakby pierwotną substancją, Wielką Matką, z której rodził się smak, kolor, obraz i fizyczne ciała"22. Dyscyplina ciała pozwala na kontrolę nad jednostką, wiąże się dla niej z przemocą i cierpieniem w przypadku Siomgi posiadanie ciała nie niesie ze sobą praktycznie żadnej korzyści dla protagonistki powieści.

\section{Wnioski}

W rzeczywistości wtłaczającej jednostkę w konkretne ramy, dyscyplinujące i ograniczające ją, zwrócenie się ku swojemu ciału staje się ucieczką ze strefy kontrolowanej. Ciało w powieści Andruchowycz funkcjonuje jako „,centralna kategoria organizująca materię i kształt (soma)tekstu. Jest imaginarium, zespołem argumentów i znaczeń, struktura retoryczną i estetyczną, a także fundamentem tożsamości’"23. Rozkładając na części pierwsze swoją osobowość i ciało (nie tylko własne), protagonistka powieści próbuje zrekonstruować swoją tożsamość, ułożyć ją z wielu dostępnych jej elementów. Poszukiwanie tożsamości nie jest w dzisiejszych czasach pojedynczym, odosobnionym przypadkiem,

${ }^{21}$ M. Foucault, Nadzorować i karać. Narodziny więzienia, tłum. T. Komendant, Warszawa 1993, s. 155-156.

${ }^{22}$ Tamże, s. 161.

${ }^{23}$ U. Śmietana, Od écriture féminine..., s. 169. 
a staje się ono zbiorem problemów, które jednostka dzieli z wciąż rosnącą liczbą ludzi, a w praktyce wręcz ze wszystkimi żyjącymi w epoce „płynnej nowoczesności”24. Doświadczenie to wiąże się raczej z jej wytwarzaniem i podejmowaniem wysiłku na rzecz posiadania tożsamości niż tylko jej odkrywanie, jako rzeczy już istniejącej ${ }^{25}$.

Kulminacją Somgi jest ostatni rozdział Chce poznać twój świat wewnętrzny, który wraz z pierwszym rozdziałem Pan światła, władca wody tworzy klamrę kompozycyjną powieści, gdyż łączy je postać postronnego obserwatora. Podglądacz towarzyszy bohaterce w jej próbach skonstruowania tożsamości z pofragmentowanych doświadczeń ciała, wspomnień i zapachów. Cielesność jest tu zarówno przestrzenią, jak i narzędziem ekspresji ${ }^{26}$. Andruchowycz w sposób niejednoznaczny kończy swoją powieść: główna bohaterka zostaje pozbawiona ciała przez mężczyznę, który pragnie przywłaszczyć sobie jej wnętrzności: „Cienkie ostrze rozcięło najpierw promienie słońca, wypędzając je z linii moich obojczyków. A potem chlusnęła fontanną krew, tak czerwona, że mężczyzna nie mógł znieść jej widoku, ale wycierał ją sobie z oczu i nie odwracał spojrzenia - szczęśliwa krew opuściła swoje więzienie [podkreślenie - A. R.] i przywitała świat potężną fontanną radości ży-

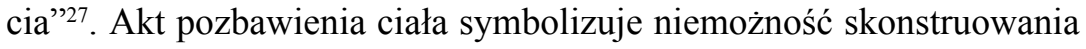
tożsamości na gruncie ukraińskiej, postkolonialno-posttotalitarnej rzeczywistości. Jest prawdopodobne, że powieściowy podglądacz to postać wyimaginowana; sama bohaterka czuje się obserwowana czy wręcz śledzona, jednak to jej własny umysł, a także wszelkie praktyki dyscyplinujące ciało są dla niej ograniczeniem. Ciało było dla niej więzieniem, które w pierwszej kolejności musiała oswoić, zadomowić się w nim, aby móc wyjść poza jego granice - uwolnić się.

${ }^{24}$ Z. Bauman, Tożsamość. Rozmowy z Benedetto Vecchim, tłum. J. Łaszcz, Gdańsk 2006, s. 15 .

${ }^{25}$ Tamże, s. 18.

${ }^{26}$ Zob. U. Śmietana, Od écriture féminine..., s. 171.

${ }^{27}$ S. Andruchowycz, Siomga, s. 405. 


\section{Bibliografia}

Agejewa W., Kobieta-autor i kobieta-czytelnik we wspótczesnej literaturze ukraińskiej, [w:] E. Kraskowska (red.), Literatury stowiańskie po roku 1989. Nowe zjawiska, tendencje, perspektywy, t. 2: Feminizm, Warszawa 2005.

Andruchowycz S., Siomga, thum. M. Petryk, Wołowiec 2009.

Bakuła B., Europa Środkowo-Wschodnia i jej (post)kolonialny świat, [w:] B. Bakuła (red.), Dyskurs postkolonialny we współczesnej literaturze i kulturze Europy Środkowo-Wschodniej. Polska, Ukraina, Wegry, Słowacja, Poznań 2015.

Bauman Z., Tożsamość. Rozmowy z Benedetto Vecchim, tłum. J. Łaszcz, Gdańsk 2006.

Braidotti R., Podmiot $w$ feminizmie, thum. A. Borowska, „Kwartalnik Pedagogiczny", 1/2/1995.

Dziadek A., Projekt krytyki somatycznej, Warszawa 2014.

Foucault M., Nadzorować i karać. Narodziny więzienia, thum. T. Komendant, Warszawa 1993.

Hyży E., Kobieta, ciało, tożsamość. Teorie podmiotu $w$ filozofii feministycznej końca XX wieku, Kraków 2012.

Śmietana U., Od écriture féminine do somatekstu, „Przegląd Filozoficzno-Literacki”, 1(3)/2003.

Świerkosz M., Feminizm korporalny w badaniach literackich. Próba wyjścia poza metaforykę cielesności, „Teksty Drugie”, 1-2/2008.

Гундорова Т., Postorientalizm, romans imigrancki $i$ nowe możliwości studiów postkolonialnych $w$ Europie Wschodniej: „Zarys dziejów traktora po ukraińsku Mariny Lewyckiej”, tłum. M. Mularczyk, „Miscellanea Posttotalitariana Wratislaviensia", 2/2014.

Поліщук Я., Реактивність літератури, Київ 2016.

Софія Андрухович: „Сьомга” - уявний сеанс психотерапії. I стриптиз. I хаpaкipi..., http://portal.lviv.ua/ratusha/2007/04/12/143153 [dostęp: 18.10.2016].

\section{Body as the foundation of identity? Attempt at (re)constructing the female identity based on Siomga by Ukrainian writer Sophia Andrukhovych}

The Author analyses Sophia Andrukhovych's novel 'Siomga' (2007) - the story of the leading character, Sofija (the author gave the protagonist her own name) is based in large part on body memory. A young woman, whose first experiences with her own 
carnality and sexuality occur during the years of the political turn, recounts the events of childhood and adolescence, and her world is ruled by emotions and feelings. In her memories, Andrukhovych's protagonist evokes the images of sexual violence against women and children and the story itself ends with the dismemberment of her body by a man who craved her viscera. Through the act of depraving of the body the author expressed the inability to reconstruct one's own identity in the Ukrainian postmodern, post-colonial and post-totalitarian reality. The novel can be analysed not only from the perspective of post-colonial and post-totalitarian studies but also within the framework of corporeal feminism.

Key words: corporeal feminism, carnality, identity, Ukrainian women's literature 